\title{
Measurement of technical performance in surgery for congenital heart disease: The stage I Norwood procedure
}

Emile A. Bacha, MD, ${ }^{a}$ Luis A. Larrazabal, MD, ${ }^{a}$ Frank A. Pigula, MD, ${ }^{a}$ Kimberlee Gauvreau, ScD, ${ }^{b}$ Kathy J. Jenkins, MD, ${ }^{b}$ Steve D. Colan, MD, ${ }^{b}$ Francis Fynn-Thompson, MD, ${ }^{a}$ John E. Mayer, Jr, MD, and Pedro J. del Nido, MD ${ }^{a}$

丹 Supplemental material is available online.
From the Departments of Cardiac Surgery ${ }^{\mathrm{a}}$ and Cardiology, ${ }^{\mathrm{b}}$ Children's Hospital Boston, Harvard Medical School, Boston, Mass.

Received for publication Nov 12, 2007; accepted for publication Dec 16, 2007.

Address for reprints: Emile A. Bacha, MD, Harvard Medical School, Cardiac Surgery, Children's Hospital Boston, 300 Longwood Ave, Boston, MA 02115 (E-mail: emile. bacha@cardio.chboston.org).

J Thorac Cardiovasc Surg 2008;136:993-7 $0022-5223 / \$ 34.00$

Copyright $\odot 2008$ by The American Association for Thoracic Surgery

doi:10.1016/j.jtcvs.2007.12.091
Objective: No method of measuring technical performance exists for the stage I Norwood procedure. Hospital mortality is usually used as a surrogate for technical performance, but evidence is lacking to support this concept. A technical score was designed by expert consensus.

Methods: The technical score included the following steps: (1) Stage I was divided into subprocedures according to anatomic areas where an intervention is performed. (2) For each subprocedure, three score categories (optimal, adequate, and inadequate) were defined on the basis of echocardiography, catheterization, and/or clinical data. (3) Subprocedures were analyzed for the whole group and by surgeon. (4) Overall repair was also scored: optimal if all attempted subprocedures were optimal, inadequate if any was inadequate, and adequate for everything in between. (5) All patients undergoing the stage I procedure from January 2004 to December 2006 were retrospectively studied.

Results: One hundred ten patients were included (operated on by six surgeons), and 4 were excluded for lack of reliable postoperative data. Most subprocedures were scored as optimal. Subprocedures with the largest inadequate scores were distal arch reconstruction in $7(6 \%)$ patients and aortopulmonary shunt in $3(5 \%)$. No statistical differences were found among surgeons either by subprocedure or by overall outcome, although individual sample sizes were small. The overall score correlated with length of stay, extracorporeal membrane oxygenator support, and hospital mortality.

Conclusions: Technical performance can be measured after the stage I procedure, and performance score correlates with early outcome. This score may also be useful as a self-assessment tool.

$\mathrm{T}$ The stage I Norwood surgical palliation (stage I) is currently the standard of treatment for neonates with hypoplastic left heart syndrome and related malformations. Although constant improvements in early diagnosis, characterization of risk factors, and treatment strategies have significantly reduced mortality for this group of patients, ${ }^{1}$ the stage I operation remains one of the most technically challenging and high-risk surgical procedures in congenital heart disease, as reflected by its position in the higher categories in either the Risk Adjusted classification for Congenital Heart Surgery (RACHS-1) and Aristotle risk adjustment methods. ${ }^{2,3}$

Until recently, hospital mortality was used as a surrogate for technical performance in surgery for congenital heart disease. However, there is little available data on the importance of technical performance in determining outcomes, independent of anatomic factors and postoperative care management. Although risk-adjusted mortality evaluations allowed a better understanding than general mortality rates, they were not intended to evaluate individual surgical performance. ${ }^{4}$ Consequently, we $\mathrm{e}^{5}$ have previously piloted a method to measure technical performance in surgery for congenital heart disease. 


\section{Abbreviations and Acronyms \\ BT $=$ Blalock-Taussig \\ ECMO = extracorporeal membrane oxygenation \\ RACHS-1 = The Risk Adjusted classification for Congenital Heart Surgery \\ RV-PA = right ventricle-pulmonary artery}

The aim of this study is to extend this methodology to the stage I Norwood procedure and to explore possible correlations between technical performance and clinical outcomes, as well as means of self-evaluation.

\section{Methods}

The Children's Hospital Boston Internal Review Board approved this study. A waiver of informed consent was obtained. Patient data were rendered anonymous in our database in compliance with the hospital requirements.

\section{Creation of the Measurement Tool}

A predischarge technical score was created by dividing the surgical procedure into individual components defined as "subprocedures," which are based on the specific anatomic regions subject to intervention. The subprocedures were as follows: atrial septectomy, aortic root reconstruction (coronary perfusion), proximal aortic arch reconstruction (distal to sinotubular junction but proximal to innominate artery), distal aortic arch reconstruction, and source of pulmonary blood flow (Blalock-Taussig [BT] shunt or right ventricle-pulmonary artery [RV-PA] conduit). For each subprocedure, score categories were defined as optimal, adequate, and inadequate. The parameters for score assessment were based on clinical, echocardiographic, and cardiac catheterization data and defined by consensus of a group of cardiologists and cardiac surgeons at our institution (Appendix E1). An overall score was also defined, wherein the operation was graded as optimal if all subprocedures were optimal; adequate if the subprocedures were optimal or adequate, but none inadequate; and inadequate if one or more subprocedures were inadequate.

The same subprocedures were also graded at the time of the preGlenn catheterization or magnetic resonance imaging, by creating definitions for a second "pre-Glenn" technical score. Surviving patients who had undergone the Glenn procedure at the time of the study were included. Trends and correlations between the two scores were explored (Appendix E2).

\section{Data Collection}

A retrospective review of all patients undergoing stage I palliation from January 2004 to December 2006 at Children's Hospital Boston was performed. Clinical data (echocardiograms, clinical evaluation, and catheterization) were collected for assessment. Other variables collected for analysis included surgeon identification, preoperative patient characteristics (age and weight at operation, noncardiac anomalies, anatomic subtype, prematurity, and presence of restrictive atrial septum), procedural characteristics (cardiopulmonary bypass times and complications, myocardial protection problems, and bleeding), and postoperative patient characteristics (reinterventions, length of stay, and in-hospital mortality). Patients who did not have any reliable clinical or echocardiographic information relevant to the technical score (ie, only available echocardiograms under extracorporeal membrane oxygenator [ECMO] support $[\mathrm{n}=2]$ or in-hospital death occurring before any testing $[\mathrm{n}=2]$ were excluded. Before they were formally excluded, their records were analyzed by all coauthor surgeons to ensure that we could not categorize them on the basis of available clinical data.

\section{Data Analysis}

Technical scores were tabulated both overall and for each of the component subprocedures. Fisher's exact test was used to explore the relationships between the technical score and patient characteristics and outcomes (eg, hospital mortality or surgeon). The Kruskal-Wallis test was used to explore relationships between technical outcome and continuous variables (length of stay). Possible associations between the predischarge score and pre-Glenn scores were explored by the Wilcoxon signed rank test.

\section{Results}

One hundred fourteen cases of stage I palliation were identified. One hundred ten patients were included and 4 were excluded for lack of reliable postoperative data (Table 1). None of the patients excluded were low-risk patients with favorable anatomy.

The procedures were performed by six attending surgeons who performed $26 \%, 25 \%, 19 \%, 16 \%, 9 \%$, and $4 \%$, respectively. A complete echocardiogram was performed at a median of 8 days (range $1-40$ days) after the operation. The median age at operation was 5 days (range $2-42$ days). Table 2 summarizes the demographic, anatomic, clinical, and surgical characteristics. Hospital mortality for the study group was $10(9 \%)$ of 110 . It is $12 \%(14 / 114)$ if one includes the 4 excluded patients. The technical performance was graded as optimal in $76(70 \%)$, adequate in 17 (16\%), and inadequate in 15 (14\%) of the patients. Table 3 summarizes subprocedural outcomes. Most of the scores in every subprocedure were classified as optimal. The subprocedures with the biggest proportion of inadequate scores were distal arch reconstruction $(6 \%)$ and BT shunt $(5 \%)$.

There were few differences in technical performance based on patient characteristics (Table 4). However, patient outcomes were different based on the technical score, and worsened across the three scoring categories. In particular, inadequate scores markedly increased risk for all clinical outcomes; risk was nearly 5-fold higher for both in-hospital death and use of ECMO, and length of stay was nearly twice as long (Table 5 and Figures 1 and 2).

The pre-Glenn score is presented in Table 6. When compared with the stage I score, a trend toward shifting from the optimal to the adequate category was noted in every subprocedure. This trend was significant for the RV-PA conduit $(P=.0001)$, for the atrial septectomy $(P=.01)$, and for the modified BT shunt $(P=.05)$. The distal arch had the biggest proportion of inadequate scores $(7 \%)$.

No statistical differences were found among surgeons either by subprocedure or by overall outcome, although individual sample sizes were small. 
TABLE 1. Patients excluded $(n=4)$

\begin{tabular}{|c|c|c|c|c|}
\hline Anatomy & Risk factor & Data available & Outcome & Comment \\
\hline $\begin{array}{l}\text { Congenital MS } \\
\text { with moderate } \\
\text { HLV, Noonan } \\
\text { syndrome }\end{array}$ & Hydrops fetalis & $\begin{array}{l}\text { No reliable echo data. No } \\
\text { evidence for technical } \\
\text { problems by clinical } \\
\text { observations }\end{array}$ & $\begin{array}{l}\text { Left OR in stable } \\
\text { condition. Died POD } 2 \\
\text { (sudden cardiac arrest) }\end{array}$ & $\begin{array}{l}\text { No reliable data re } \\
\text { technical performance }\end{array}$ \\
\hline HLHS (AA/MS) & On ECMO preop & $\begin{array}{l}\text { No reliable echo data. No } \\
\text { evidence for technical } \\
\text { problems by clinical } \\
\text { observations. On } \\
\text { ECMO before and after } \\
\text { surgery owing to } \\
\text { pulmonary disease }\end{array}$ & $\begin{array}{l}\text { Unable to wean from CPB } \\
\text { owing to poor } \\
\text { pulmonary function. } \\
\text { In-hospital death (POD } \\
\text { 3). Final diagnosis at } \\
\text { autopsy: alveolar } \\
\text { capillary dysplasia }\end{array}$ & $\begin{array}{l}\text { No reliable data re } \\
\text { technical performance }\end{array}$ \\
\hline $\begin{array}{l}\text { HLHS (AS/MS), } \\
\text { heterotaxy/ } \\
\text { polysplenia. }\end{array}$ & $\begin{array}{l}\text { Dysplastic pulmonary } \\
\text { valve with moderate/ } \\
\text { severe regurgitation }\end{array}$ & No reliable echo data & $\begin{array}{l}\text { Left OR on high-dose } \\
\text { inotropes in critical } \\
\text { condition. In-hospital } \\
\text { death (POD 0) }\end{array}$ & $\begin{array}{l}\text { No reliable data re } \\
\text { technical performance }\end{array}$ \\
\hline $\begin{array}{l}\text { HLHS (AA/MS), } \\
\text { intact atrial } \\
\text { septum, s/p } \\
\text { emergency } \\
\text { postnatal } \\
\text { atrial stenting }\end{array}$ & LV-coronary fistulas & $\begin{array}{l}\text { No echo data. } \\
\text { Transitioned to ECMO } \\
\text { intraop because of low } \\
\text { CO. Signs of posterior } \\
\text { wall ischemia despite } \\
\text { probe- patent proximal } \\
\text { left coronary system }\end{array}$ & $\begin{array}{l}\text { Died POD } 1 \text { owing to } \\
\text { diffuse thrombosis of } \\
\text { ECMO circuit. Autopsy } \\
\text { showed signs of early } \\
\text { posterior wall } \\
\text { myocardial infarction }\end{array}$ & $\begin{array}{l}\text { Excluded because } \\
\text { technical coronary } \\
\text { reconstruction } \\
\text { problems vs effect of } \\
\text { LV-dependent coronary } \\
\text { fistulas could not be } \\
\text { demonstrated }\end{array}$ \\
\hline
\end{tabular}

$M S$, Mitral stenosis; $H L V$, hypoplasic left ventricle; $O R$, operating room; $P O D$, postoperative day; $H L H S$, hypoplastic left heart syndrome; $A A / M S$, aortic atresia and mitral stenosis; $E C M O$, extracorporeal membrane oxygenation; $C P B$, cardiopulmonary bypass; $A S / M S$, aortic stenosis and mitral stenosis; $s / p$, status post; $L V$, left ventricle; $C O$, cardiac output.

TABLE 2. Patient and procedure characteristics $(n=110)$

\begin{tabular}{lcl}
\hline & n (\%) or median (range) \\
\hline Age at operation (d) & 5 & $(2-42)$ \\
$>14$ days at operation & 6 & $(5 \%)$ \\
Weight $(\mathrm{kg})$ & 3.2 & $(1.3-4.7)$ \\
Weight $<2500 \mathrm{~g}$ & 17 & $(15 \%)$ \\
Major noncardiac structural anomaly & 4 & $(4 \%)$ \\
Prematurity & 12 & $(11 \%)$ \\
Female gender & 40 & $(36 \%)$ \\
Length of stay (d) & 18 & $(1-141)$ \\
In-hospital mortality & 10 & $(9 \%)$ \\
Intact or restrictive septum & 16 & $(15 \%)$ \\
Morphologic variants & & \\
$\quad$ AA/MA & 30 & $(27 \%)$ \\
AA/MS & 11 & $(10 \%)$ \\
AS/MA & 4 & $(4 \%)$ \\
AS/MS & 33 & $(30 \%)$ \\
$\quad$ Others & 32 & $(29 \%)$ \\
CPB times (min) & 143 & $(87-312)$ \\
CPB & & \\
Crossclamp & 61 & $(0-189)$ \\
Circulatory arrest & 37 & $(0-189)$ \\
\hline AA MA, Aotic atria & &
\end{tabular}

$A A / M A$, Aortic atresia and mitral atresia; $A A / M S$, aortic atresia and mitral stenosis; $A S / M A$, aortic stenosis and mitral atresia; $A S / M S$, aortic stenosis and mitral stenosis; $C P B$, cardiopulmonary bypass.

\section{Discussion}

Public interest in outcomes for cardiac surgery has significantly increased in the past decade. For example, the state of Massachusetts now requires the mandatory collection of data by hospitals assessing individual congenital heart surgeons' performance. ${ }^{6}$ Also, with the current evolution of health care towards performance-based reimbursements ("Pay-for-Performance", or P4P), ${ }^{7}$ it becomes imperative

TABLE 3. Stage I technical score $(n=110)$

\begin{tabular}{|c|c|c|c|c|c|}
\hline & Optimal & Adequate & Inadequate & N/A & Total \\
\hline Overall score & $77(70 \%)$ & $18(16 \%)$ & $15(14 \%)$ & 0 & 110 \\
\hline \multicolumn{6}{|l|}{ Subprocedure score } \\
\hline $\begin{array}{l}\text { Proximal arch } \\
\text { reconstruction }\end{array}$ & $106(96 \%)$ & 0 & $3(3 \%)$ & $1(1 \%)$ & 110 \\
\hline $\begin{array}{l}\text { Distal arch } \\
\text { reconstruction }\end{array}$ & $88(80 \%)$ & $12(11 \%)$ & $7(6 \%)$ & $3(3 \%)$ & 110 \\
\hline Coronary perfusion & $107(97 \%)$ & 0 & $1(1 \%)$ & $2(2 \%)$ & 110 \\
\hline Atrial septectomy & $109(99 \%)$ & 0 & 0 & $1(1 \%)$ & 110 \\
\hline \multicolumn{6}{|l|}{$\begin{array}{c}\text { Pulmonary blood } \\
\text { source }\end{array}$} \\
\hline Modified BT shunt & $53(83 \%)$ & $6(9 \%)$ & $3(5 \%)$ & $2(3 \%)$ & 64 \\
\hline RV-PA conduit & $44(96 \%)$ & $1(2 \%)$ & $1(2 \%)$ & 0 & 46 \\
\hline
\end{tabular}

$N / A$ (not assessed), No information on this subprocedure on echocardiogram; $B T$, Blalock-Taussig; $R V-P A$, right ventricle-pulmonary artery. 


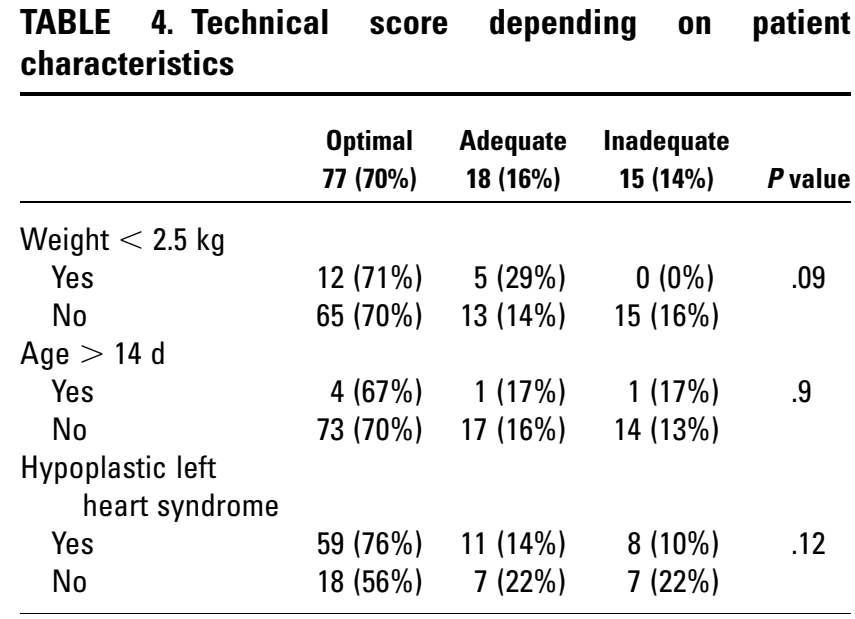

for congenital heart surgeons to define optimal or acceptable surgical performance. ${ }^{8,9}$ Congenital heart surgeons have very few, if any, available tools for use for systematic self-assessment as part of an on-going quality improvement evaluation process. Because technical performance is very difficult to quantify and measure directly, hospital mortality, usually in the form of a cumulative sum analysis,${ }^{10}$ is often used as a surrogate for measuring performance in heart surgery. While risk-adjusted in-hospital death rates may be a reasonable measure of institutional performance, this measure is inadequate to assess the performance of individual practitioners, because many additional factors, outside of the control of an individual surgeon, may contribute to mortality. This is especially problematic for single ventricle palliation, which requires a complex multidepartmental team consisting of many individuals and specialties. We have previously developed a technical scoring system for common congenital heart procedures. ${ }^{5}$ The present study represents a first attempt at defining and measuring technical performance for the stage I Norwood operation.

The present stage I score was defined by expert consensus. This was a difficult undertaking, as there are no prior guidelines. We found that the overall outcome was optimal in $70 \%$, adequate in $16 \%$ and inadequate in $14 \%$ of the patients. The 3 outcome levels correlated with the mortality rates: $5 \%, 11 \%$ and $27 \%$ respectively $(P=0.02)$, suggesting a strong impact of technical performance on hospital survival in stage I patients. Furthermore, the 5\% mortality rate in the "optimal" category also suggests that while excellent technical results

TABLE 5. Patient outcomes

\begin{tabular}{lcccc}
\hline & Optimal & Adequate & Inadequate & $\boldsymbol{P}$ value \\
\hline Median LOS (range) & $18(2-96)$ & $19(4-141)$ & $33(1-125)$ & .02 \\
Hospital mortality $(\mathrm{n}=8)$ & $4(5 \%)$ & $2(11 \%)$ & $4(27 \%)$ & .02 \\
ECMO & $6(8 \%)$ & $2(11 \%)$ & $8(53 \%)$ & $<.001$ \\
\hline
\end{tabular}

LOS, Length of stay; ECMO, extracorporeal membrane oxygenation.

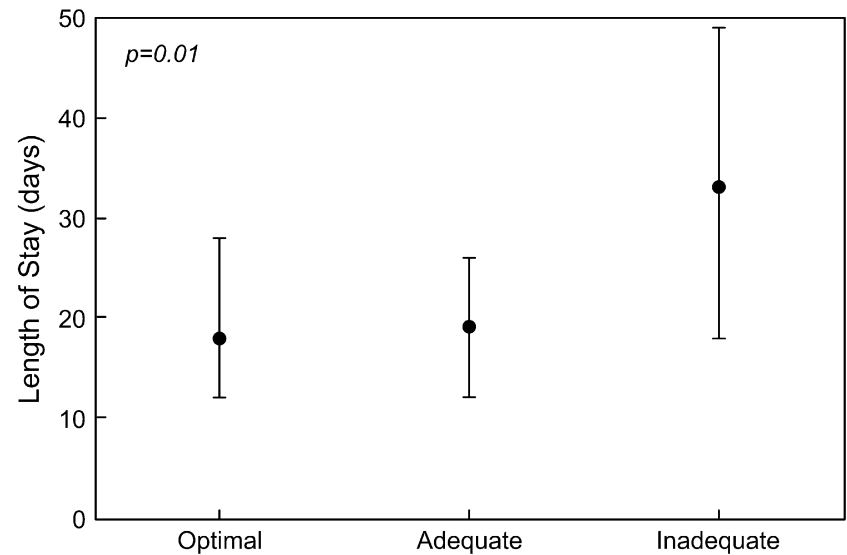

Figure 1. The relationship of Length of stay to technical performance.

are necessary for survival, they may not be sufficient. A large role is also likely played by other domains, such as structural or procedural factors, ${ }^{11}$ or patient-specific factors ("risk factors"). ${ }^{12,13}$

Because this method allows the identification of the specific sub-procedures with a bigger proportion of inadequate outcomes, it may also serve as a method of self-evaluation or internal quality assurance. This could potentially facilitate a change in practice and techniques through retraining in the specific parts of the surgery identified as underperforming. To avoid concerns regarding the generalization and misunderstanding in the interpretation of the data, this method should be used mostly for self-evaluation and training purposes, until further validation occurs.

The development of the pre-Glenn score was aimed at exploring the impact of each sub procedure on mid-term anatomic outcomes. A trend towards shifting from optimal to adequate was noted in every subprocedure, and this was significant for the RV-PA conduit and the BT shunt. The distal arch remained the area with the highest inadequate scores. It

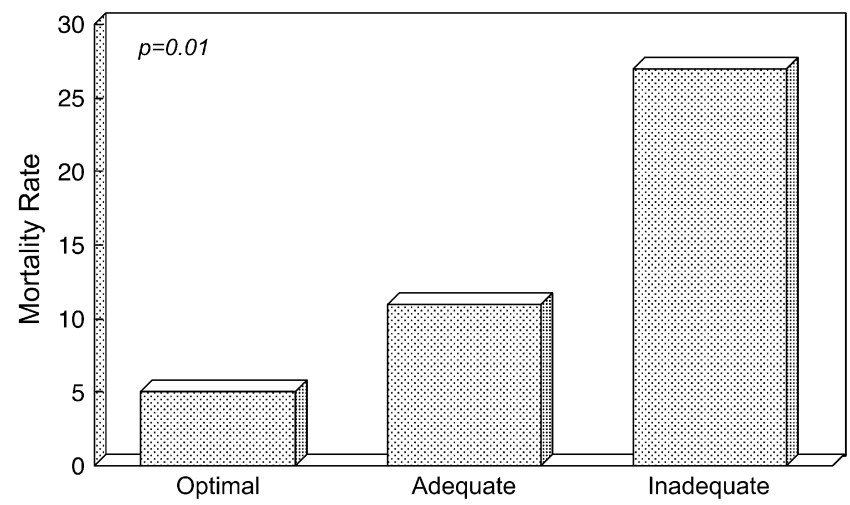

Figure 2. Mortality. 
TABLE 6. Pre-Glenn technical score $(n=75)$

Optimal Adequate Inadequate N/A Total

\begin{tabular}{lccccc}
\hline Overall score & $26(35 \%)$ & $44(58 \%)$ & $5(7 \%)$ & 0 & 75 \\
$\begin{array}{c}\text { Subprocedure score } \\
\text { Proximal arch }\end{array}$ & $73(97 \%)$ & $2(3 \%)$ & 0 & 0 & 75 \\
$\begin{array}{c}\text { reconstruction } \\
\begin{array}{c}\text { Distal arch } \\
\quad \text { reconstruction }\end{array}\end{array}$ & $52(69 \%)$ & $18(24 \%)$ & $5(7 \%)$ & 0 & 75 \\
$\begin{array}{c}\text { Coronary perfusion } \\
\text { Atrial septectomy }\end{array}$ & $74(99 \%)$ & 0 & $1(1 \%)$ & 0 & 75 \\
$\begin{array}{c}\text { Pulmonary blood source } \\
\text { Modified BT shunt }\end{array}$ & $25(92 \%)$ & $6(8 \%)$ & 0 & 0 & 75 \\
RV-PA conduit (Sano) & $18(50 \%)$ & $18(36 \%)$ & 0 & 0 & 39 \\
\hline
\end{tabular}

$B T$, Blalock-Taussig; $R V-P A$, right ventricle-pulmonary artery.

is possible that worsening of these anatomic areas was unavoidable. However, the pre-Glenn technical scoring system can have a feed-back function and informs the initial technical steps of the stage I, thus potentially lowering the number and morbidity of needed additional procedures at the second stage.

This study has several limitations. There are many other important variables for a technically optimal Stage I operation (i.e. cardiopulmonary bypass management, myocardial protection, prevention and management of bleeding, avoidance of recurrent laryngeal and phrenic nerve damage, situational awareness, etc...). We decided not to include them in the technical score because our intent was to focus on assessing the defined cardiovascular anatomic steps that comprise the stage I operation. Similarly, important steps that belong to other health care quality domains such as structure and process (i.e. pre-operative care, timely transportation of the patient to the operating room, anesthesiologists, cardiologists, nursing and supporting staff, etc) are also not accounted for. Given the strong correlation between technical score and outcome however, it is likely that these other factors play a secondary role in determining early survival and major complication rate. Although classification of patients that died as "optimal" or "adequate" may seem counterintuitive, given our aim to measure the technical outcome specifically, patient outcomes were not considered. Of note, this approach allowed us to identify 4 neonates who died despite technically optimal surgery, highlighting the importance of non-technical factors, such as those above. Finally, risk-adjustment needs to be an important part of any performance evaluation to avoid penalization of surgeons and institutions treating more complex cases. $^{2-4}$
As opposed to our first pilot study, ${ }^{5}$ this study does not have the restriction of being based purely on echocardiography. For example, the difficulties to assess aortic arch gradients were reduced by including blood pressure and catheterization measurements, which are standard studies available in the majority of patients. However, some patients died before any meaningful post-operative study could be performed. Those patients generally were complicated cases who were on ECMO either before or immediately after surgery. We are unable to comment on the technical outcome of these procedures, based on lack of information.

In conclusion, the present score describes a method to measure technical performance after Stage I surgical palliation, and is intended to be useful to surgeons for self-evaluation. Avoidance of a technically inadequate outcome was a major determinant of survival; thus this score should be an especially useful tool to reduce mortality from this serious malformation. Future studies will focus on expanding this methodology to other procedures, prospective validation, as well as multi-center trials.

\section{References}

1. Vida V, Bacha EA, del Nido PJ, Mayer JE, Pigula FA, Tworetzky W, et al. Surgical outcome for patients with the MS-AA subtype of hypoplastic left heart syndrome. J Thorac Cardiovasc Surg. JTCVS. 2008; 135:339-46.

2. Lacour-Gayet F, Clarke D, Jacobs J, Gaynor W, Hamilton L, Jacobs M, et al. The Aristotle score for congenital heart surgery. Semin Thorac Cardiovasc Surg Pediatr Card Surg Annu. 2004;7:185-91.

3. Jenkins KJ. Risk adjustment for congenital heart surgery: the RACHS-1 method. Semin Thorac Cardiovasc Surg Pediatr Card Surg Annu. 2004; 7:180-4.

4. Jenkins KJ, Gauvreau K. Center-specific differences in mortality: preliminary analyses using the Risk Adjustment in Congenital Heart Surgery (RACHS-1) method. J Thorac Cardiovasc Surg. 2002;124:97-104.

5. Larrazabal LA, del Nido PJ, Jenkins KJ, Gauvreau K, Lacro R, Colan SD, et al. Measurement of technical performance in congenital heart surgery: a pilot study. Ann Thorac Surg. 2007;83:179-84.

6. http://www.massmedboard.org/regs $/ 243 \mathrm{cmr}$.htm.

7. Institute of Medicine. Performance measurement: accelerating improvement. Washington [DC]: The National Academies Press; 2006.

8. Treasure T, Gallivan S, Sherlaw-Johnson C. Monitoring cardiac surgical performance: a commentary. J Thorac Cardiovasc Surg. 2004;128: 823-5.

9. Grunkemeier GL, Wu YX, Furnary. AP. Cumulative sum techniques for assessing surgical results. Ann Thorac Surg. 2003;76:663-7.

10. Shahian DM, Grover FL, Anderson RP, Edwards FH. Quality measurement in adult cardiac surgery: introduction. Ann Thorac Surg. 2007;83: S1-2.

11. Donabedian A. Evaluating the quality of medical care. Millbank Mem Fund Q. 1966;44(suppl):166-20616.

12. Blackstone EH. Thinking beyond the risk factors. Eur J Cardiothorac Surg. 2006;29:645-52.

13. Stasik CN, Gelehrter S, Goldberg CS, Bove EL, Devaney EJ, Ohye RG. Current outcomes and risk factors for the Norwood procedure. J Thorac Cardiovasc Surg. 2006;131:412-7. 


\section{APPENDIX E1. Discharge technical score}

\begin{tabular}{|c|c|c|c|}
\hline Subprocedure & Optimal & Adequate & Inadequate \\
\hline $\begin{array}{l}\text { Proximal arch } \\
\text { reconstruction }\end{array}$ & $\begin{array}{l}\text { - No gradient } \\
\text { - No evidence of coronary } \\
\text { ischemia } \\
\text { - Peak velocity }<1.5 \mathrm{~m} / \mathrm{s} \\
\text { by echo }\end{array}$ & $\begin{array}{l}\text { - Mild gradient at proximal aorto- } \\
\text { pulmonary anastomosis or prox- } \\
\text { imal arch }(\Delta \mathrm{p} \leq 20 \mathrm{~mm} \mathrm{Hg} \text { by } \\
\text { echo or by cath) } \\
\text { - Peak velocity } \leq 2.5 \mathrm{~m} / \mathrm{s} \text { by echo } \\
\text { - Successful intraop revision }\end{array}$ & $\begin{array}{l}\text { - Need for reintervention during } \\
\text { initial hospital stay } \\
\text { - More than mild gradient }(\Delta \mathrm{p}>20 \\
\text { mm Hg) } \\
\text { - Peak velocity }>2.5 \mathrm{~m} / \mathrm{s} \text { by echo } \\
\text { - Clinical evidence (symptoms) of } \\
\text { "neo-supra AS" }\end{array}$ \\
\hline $\begin{array}{l}\text { Distal arch } \\
\text { reconstruction }\end{array}$ & $\begin{array}{l}\text { - No narrowing or flow } \\
\text { acceleration by echo } \\
\text { - No BP gradient } \\
\text { - Peak velocity }<2 \mathrm{~m} / \mathrm{s} \\
\text { by echo }\end{array}$ & $\begin{array}{l}\text { - Peak velocity } \leq 3 \mathrm{~m} / \mathrm{s} \text { by echo } \\
\text { - Mild gradient ( } \Delta \mathrm{p} \leq 20 \mathrm{~mm} \mathrm{Hg} \\
\text { by echo or by cath) } \\
\text { - Successful intraop revision }\end{array}$ & $\begin{array}{l}\text { - Need for reintervention during } \\
\text { initial hospital stay } \\
\text { - Peak velocity }>3 \mathrm{~m} / \mathrm{s} \text { by echo } \\
\text { - More than mild gradient ( } \Delta \mathrm{p}> \\
20 \mathrm{~mm} \mathrm{Hg} \text { ) } \\
\text { - Clinical evidence (symptoms) of } \\
\text { coarctation }\end{array}$ \\
\hline $\begin{array}{l}\text { Coronary } \\
\text { perfusion }\end{array}$ & $\begin{array}{l}\text { - Unobstructed flow into } \\
\text { proximal coronary arteries }\end{array}$ & $\begin{array}{l}\text { - Unobstructed flow into proximal } \\
\text { coronary arteries } \\
\text { - Successful intraop revision }\end{array}$ & $\begin{array}{l}\text { - Need for reintervention during } \\
\text { initial hospital stay Evidence for } \\
\text { obstructed coronary flow }\end{array}$ \\
\hline Atrial septectomy & $\begin{array}{l}\text { - No gradient } \\
\text { - restrictive atrial } \\
\text { septum left on purpose }\end{array}$ & - Mean gradient $\leq 4 \mathrm{~mm} \mathrm{Hg}$ & $\begin{array}{l}\text { - Need for reintervention during } \\
\text { initial hospital stay } \\
\text { - Mean gradient }>4 \mathrm{~mm} \mathrm{Hg}\end{array}$ \\
\hline \multicolumn{4}{|l|}{$\begin{array}{l}\text { Source of } \\
\text { pulmonary } \\
\text { blood flow }\end{array}$} \\
\hline a. Modified BT shunt & - Patent & $\begin{array}{l}\text { - Patent } \\
\text { - Downsizing of shunt because of } \\
\text { pulmonary overcirculation }\end{array}$ & $\begin{array}{l}\text { - Need for reintervention during } \\
\text { initial hospital stay } \\
\text { - Early symptomatic distortion of } \\
\text { branch PAs } \\
\text { - Symptomatic shunt narrowing } \\
\text { (clot, suture line) }\end{array}$ \\
\hline b. RV-PA conduit & - Patent & $\begin{array}{l}\text { - Patent } \\
\text { - Downsizing of shunt because of } \\
\text { pulmonary overcirculation }\end{array}$ & $\begin{array}{l}\text { - Need for reintervention during } \\
\text { initial hospital stay } \\
\text { - Early symptomatic distortion of } \\
\text { branch PAs } \\
\text { - Symptomatic conduit narrowing } \\
\text { (clot, suture line) }\end{array}$ \\
\hline
\end{tabular}

$B T$, Blalock-Taussig; RV-PA, right ventricle-pulmonary artery. Reexploration for bleeding does not count as reintervention (ie, not coded as "inadequate"). 
APPENDIX E2. Pre-Glenn score

\begin{tabular}{|c|c|c|c|}
\hline Subprocedure & Optimal & Adequate & Inadequate \\
\hline General & - & - & $\begin{array}{l}\text { - Unsuitable for BDG } \\
\text { because of anatomic } \\
\text { residua }\end{array}$ \\
\hline $\begin{array}{l}\text { Proximal arch } \\
\text { reconstruction }\end{array}$ & $\begin{array}{l}\text { - No gradient } \\
\text { - Peak velocity }<1.5 \mathrm{~m} / \mathrm{s} \\
\text { by echo } \\
\text { - No coronary inflow problem }\end{array}$ & $\begin{array}{l}\text { - } \text { Mild gradient at } \\
\text { proximal aortopulmonary anas- } \\
\text { tomosis or proximal } \\
\text { arch }(\Delta \mathrm{p} \leq 20 \mathrm{~mm} \mathrm{Hg} \\
\text { by cath or BP) } \\
\text { - Peak velocity } \leq 2.5 \mathrm{~m} / \mathrm{s} \\
\text { by echo } \\
\text { - Need for BD at pre-BDG cath }\end{array}$ & $\begin{array}{l}\text { - More than mild } \\
\text { gradient at proximal } \\
\text { aortopulmonary } \\
\text { anastomosis or } \\
\text { proximal arch } \\
(\Delta \mathrm{p}>20 \mathrm{~mm} \mathrm{Hg} \text { by } \\
\text { cath or BP) } \\
\text { - Peak velocity }>2.5 \mathrm{~m} / \mathrm{s} \\
\text { by echo } \\
\text { - Need for surgical plasty } \\
\text { of arch at BDG }\end{array}$ \\
\hline $\begin{array}{l}\text { Distal arch } \\
\text { reconstruction }\end{array}$ & $\begin{array}{l}\text { - No narrowing or flow } \\
\text { acceleration by echo } \\
\text { - No BP gradient } \\
\text { - Peak velocity }<2 \mathrm{~m} / \mathrm{s} \\
\text { by echo }\end{array}$ & $\begin{array}{l}\text { - Mild/moderate or } \\
\text { moderate narrowing } \\
\text { or flow acceleration by } \\
\text { cath or BP }(\Delta \mathrm{p} \leq 20 \mathrm{~mm} \mathrm{Hg}) \\
\text { - Peak velocity } \leq 3 \mathrm{~m} / \mathrm{s} \text { by echo } \\
\text { - Need for BD at pre-BDG cath }\end{array}$ & $\begin{array}{l}\text { - Severe narrowing or } \\
\text { flow acceleration by cath } \\
\text { or BP }(\Delta \mathrm{p}>20 \mathrm{~mm} \mathrm{Hg}) \\
\text { - Peak velocity }>3 \mathrm{~m} / \mathrm{s} \\
\text { by echo } \\
\text { - Need for surgical plasty } \\
\text { of arch at BDG }\end{array}$ \\
\hline Coronary perfusion & $\begin{array}{l}\text { - Unobstructed flow into } \\
\text { proximal coronary arteries }\end{array}$ & $\begin{array}{l}\text { - Unobstructed flow into proximal } \\
\text { coronary arteries }\end{array}$ & $\begin{array}{l}\text { Evidence for obstructed } \\
\text { coronary flow } \pm \text { ventricular } \\
\text { dysfunction }\end{array}$ \\
\hline Atrial septectomy & $\begin{array}{l}\text { - No gradient } \\
\text { - Restrictive atrial } \\
\text { septum left on purpose }\end{array}$ & $\begin{array}{l}\text { - Mean gradient } \leq 4 \mathrm{~mm} \mathrm{Hg} \\
\text { - Need for intervention at BDG }\end{array}$ & $\begin{array}{l}\text { - Mean gradient } \\
>4 \mathrm{~mm} \mathrm{Hg} \\
\text { - Evidence for pulmonary } \\
\text { hypertension owing to } \\
\text { restrictive atrial septum } \\
\text { - Need for reintervention } \\
\text { before BDG }\end{array}$ \\
\hline \multicolumn{4}{|l|}{$\begin{array}{l}\text { Source of pulmonary } \\
\text { blood flow }\end{array}$} \\
\hline c. Modified BT shunt & $\begin{array}{l}\text { - Patent } \\
\text { - Flow into both proximal branch } \\
\text { PAs by echo } \\
\text { - Cath: smooth proximal } \\
\text { and distal anastomosis }\end{array}$ & $\begin{array}{l}\text { - Patent } \\
\text { - Some branch PA distortion at } \\
\text { pre-BDG cath } \pm \text { need for BD }\end{array}$ & $\begin{array}{l}\text { - need for reintervention } \\
\text { during interstage (before } \\
\text { the scheduled pre-BDG } \\
\text { cath) }\end{array}$ \\
\hline d. RV-PA conduit & $\begin{array}{l}\text { - Patent } \\
\text { - Flow into both proximal branch } \\
\text { PAs by echo } \\
\text { - cath: smooth proximal } \\
\text { and distal anastomosis }\end{array}$ & $\begin{array}{l}\text { - Patent } \\
\text { - Some branch PA distortion at } \\
\text { pre-BDG cath } \\
\text { - Some proximal narrowing at pre- } \\
\text { BDG cath } \pm \text { need for BD }\end{array}$ & $\begin{array}{l}\text { - need for reintervention } \\
\text { during interstage } \\
\text { (not during scheduled } \\
\text { pre-BDG cath) }\end{array}$ \\
\hline
\end{tabular}

$B D$, Balloon dilation; $B D G$, bidirectional Glenn shunt; $P A$ : pulmonary artery; $B T$, Blalock-Taussig; $R V-P A$, right ventricle-pulmonary artery. 